\title{
Dynamic Capabilities: the missing link in CRM investments
} $(66 / 07)$

\section{Abstract}

\section{Purpose}

This paper illustrates the practical application of Dynamic Capabilities theory to improve investment decisions in Customer Relationship Management (CRM).

\section{Design/methodology/approach}

Action Research (AR) allows managers to raise the tacit knowledge of their

Dynamic Capabilities to a level where they can be identified and developed. A framework and process for managing Dynamic Capabilities in marketing are presented.

\section{Findings}

The findings relate to the nature of Dynamic Capabilities in marketing and how they are managed.

\section{Practical implications}

Marketing managers can improve the return on investments in CRM. 


\section{Originality/value}

The paper presents a method for applying Dynamic Capabilities drawn from the Resource Based View (RBV) to practical marketing problems.

\section{Keywords}

RBV, Dynamic Capabilities, Action Research, CRM

\section{Paper type}

Empirical 


\section{Authors:}

Dr Stan Maklan is Senior Lecturer in Strategic Marketing at Cranfield School of Management. s.maklan@cranfield.ac.uk. Prior to joining academe, Stan had 20 years senior, international experience with international blue chip organisations in consumer marketing, marketing services and IT-Management consulting. Stan established the UK CRM practice for a world leader in IT services. His research interests are capability development, CRM, customer experience, organisational brand development and the application of advanced financial theory to marketing decision making.

Professor Simon Knox holds the Chair in Brand Marketing at Cranfield School of Management. s.knox@cranfield.ac.uk. Simon has published over 100 papers and books on strategic marketing and branding and is a regular speaker at international conferences. He is currently leading research looking at the impact of corporate social responsibility on brand management, and branding in not-for-profit organisations.

Please address all correspondence to Dr Maklan either by email (preferred) or in writing to Cranfield School of Management, Cranfield, Bedfordshire, MK43 OAL, UK. 


\section{Introduction}

Do you remember how Customer Relationship Management (CRM) was going to change the fundamental rules of marketing within the firm (Sheth and Sisodia, 1999). Pine et al (1995) argued that customers would relish ever more personalised service and would co-develop solutions with supply networks (Hagel and Singer Marc, 2000) to unleash greater value-in-use for their purchases (Vargo and Lusch, 2004). Companies would also benefit from this fundamental shift since most customers inherently value relationships (Sheth and Parvatiyar, 1995) and small increases in customer retention would deliver significant increases in profitability over the lifetime of these relationships (Reichheld, 1996).

In reality, events have turned out very differently. Between 2000 and 2005, firms invested $\$ 220$ billion in CRM solutions (Payne, 2006) and yet the majority of firms fail to deliver targeted ROI on their investments (Roberts, Liu and Hazard, 2005; Rigby, Reichheld and Schefter, 2002;

PricewaterhouseCoopers, 2002). Customer satisfaction levels have not improved during this time either; the US customer satisfaction index has barely changed over the past decade ${ }^{1}$. In fact, we would argue that it is one of the great paradoxes of these unprecedented levels of marketing investment in CRM that has left customers ever more cynical and disloyal.

The literature dealing with CRM successes and failures highlights the critical role of culture (Bohling, Bowman, LaValle et al, 2006; Shah, Rust, Parasuraman et al, 2006; Kale, 2004), organisational alignment (Boulding, 
Staelin, Ehret et al, 2005; Roberts, Liu and Hazard, 2005) appropriate use of customer lifetime value analysis (Ryals, 2005; Reinartz and Kumar, 2002; Venkatesan and Kumar, 2004) and motivating employees to improve customer management (Zablah, Bellenger and Johnston, 2004; Bohling, Bowman et al, 2006).

However, we believe that CRM can be severely compromised even before the implementation process begins and the above factors impact the outcomes. This is because the discounted cash flow (DCF) analysis that dominates business case thinking often locks marketers into CRM strategies before they have learnt how customers wish to engage with the firm (Maklan, Knox and Ryals, 2005). The traditional business case assumes that, as a result of CRM investment, consumer behaviour will change by a pre determined amount in order to justify the incremental revenue identified in the business case. Thus, the CRM sequence is regarded as linear: analysis-business case-investmentto acquire resources-implement CRM-change consumer behaviour-profit.

We do not regard such a linear approach is appropriate for CRM investment decision making and adopt a Dynamic Capabilities perspective (Teece, Pisano and Shuen, 1997) which suggests that CRM investment must account for the heterogeneity of individual firms' CRM resources and capabilities. Not all firms can successfully implement the CRM strategy and processes offered by CRM software vendors, particularly when their dynamic CRM capabilities are lacking. 
In this paper, we argue that companies have invested heavily in CRM resources (databases, web sites, analytical tools, call centres) but insufficiently in the Dynamic Capabilities required to select, develop and deploy these CRM resources effectively (Teece, Pisano et al, 1997). We further argue that this arises because Dynamic Capabilities are grounded in managers' tacit knowledge of the business and are therefore notoriously difficult to identify, let alone manage. We explore how such Dynamic Capabilities can be surfaced using Action Research amongst the management of two organisations facing major CRM investment decisions: decisions that would have profound implications for marketing strategy. In both instances, an emergent approach to building the firm's CRM investment strategy led to a much greater awareness of the Dynamic Capabilities needed to support CRM and to changes in how customer relationship investment was managed. First, we provide the context for our research, that is, the companies involved and the marketing/customer relationship problems faced by each. Then we describe our research method and process, and the results which led to the surfacing of tacit knowledge about the Dynamic Capabilities in each firm and how investment in marketing resources was subsequently developed as a result. We close the paper with a section on the limitations of our research and offer directions for further research.

In the next section, we briefly explore the literature on Dynamic Capabilities; how it has evolved from the Resource Based View, its definition and why the nature of Dynamic Capabilities has blurred both the development of theory and practice in this area. 


\section{What are Dynamic Capabilities and why have they}

\section{been overlooked?}

The Resource Based View (RBV) is the dominant theory in Strategy literature (Newbert, 2007); it explains sustained, superior performance as a function of the heterogeneity of firm-specific resources such as brands, customer relationships and distribution partnerships (Barney, 1991). Marketing scholars intuitively appreciate the link between such resources and competitiveness. Indeed, RBV is considered by some to be the theoretical core of marketing (Day and Van den Bulte, 2002; Day, 1999b; Srivastava, Shervani and Fahey, 1998; Hunt, 2000). However, others feel that RBV has failed to make a major contribution to our understanding of competitiveness as the definition of resources is vague and tautological (Priem and Butler, 2001). The theory of Dynamic Capabilities side-steps this criticism by focusing less upon identifying the "static" advantage-creating resources, such as brands, to focus more upon exploring how these resources are created and used for competitive advantage. Thus, our definition of this phenomenon is as follows:

"Dynamic capabilities are the antecedent organisational and strategic routines by which managers alter their resource base....to create new value-creating strategies. ...They are the drivers behind the creation, evolution and recombination of other resources into new sources of competitive advantage" (Eisenhardt and Martin, 2000:1107). 
This definition implies that the firm is better able than its competitors at learning from customers (Vargo and Lusch, 2004), more adept at changing core business processes and routines (Winter, 2003; Eisenhardt and Martin, 2000) and continually reconfigures, enhances and deploys (Rindova and Kotha, 2001; Teece, Pisano and Shuen, 1997) resources in a manner that creates superior customer value and hence superior performance in the marketplace.

However, the vary nature of these Dynamic Capabilities means that they are very difficult to manage and develop. Scholars liken the challenge of identifying and managing them to "observing the unobservable" (Rouse and Daellenbach, 1999; Godfrey and Hill, 1995). Dynamic Capabilities arise from the everyday tasks of the firm's employees (Eisenhardt and Martin, 2000) and are often the unquestioned "how we do things around here" activities that permit some firms to distinguish themselves, for example, by providing better customer service than their competitors. They are grounded in tacit knowledge (Polanyi, 1976) which ensures that they are not easily documented, transferred internally between business units and, more importantly, cannot readily be imitated by competitors. Dynamic Capabilities exist in complex bundles with other capabilities and resources (Black and Boal, 1994). It is therefore difficult for managers to identify, let alone assess the impact of any one Dynamic Capability on market performance. In certain circumstances, Dynamic Capabilities can be linked to competitive advantage and ultimately to superior profitability but, because of the inherent difficulties of managing and measuring these internal drivers, casual ambiguity rather 
clouds the picture and can deter empirical research among marketing scholars.

This management problem in most organisations is further compounded by our assertion that it is unclear as to who exactly is responsible for ensuring their development. Change programmes arising from new business processes, such as CRM, are directed almost exclusively by the IT function (CSC Index, 1994). Therefore, we posit that those in charge of CRM implementation view the development of relationship marketing capability as little more than training marketers to use the new technology and to deploy related business processes, rather than helping marketers to innovate new marketing programmes that affect customers' attitudes and behaviours favourably. Even where the CRM investment leaders do go further and provide individual skills development for marketers, we would argue that Dynamic Capabilities are not merely the sum of individuals' knowledge (Teece and Pisano, 1994); they originate and grow within the firm through employee collaboration. Thus, the focus on Dynamic Capability development must be at a team level.

\section{Presenting a framework for surfacing and developing}

\section{Dynamic Capabilities}

Marketing managers lack a pragmatic framework to first identifying and then developing the Dynamic Capabilities needed to invest in CRM successfully (Maklan, 2004). The authors develop such a framework for consumer markets 
(Figure 1) from the extant work of both Webster (1992) and Coviello et al (2002) albeit the authors focus on consumer marketing.

Webster's widely cited article ${ }^{2}$ identifies a shift in the conceptualisation of marketing to help organisations align internal operations to support different types of marketing relationships. He identifies a seven point continuum of marketing relationships: transactions, repeated transactions, long term relationships, buyer-seller partnerships, strategic alliances, network organisations and vertical integration. In order to develop a conceptual framework that can be made operational by managers, we further reduced Webster's continuum $^{3}$ to three main types of marketing relationships:

- Transactional - comprising that which Webster identified as transactions and repeated transactions

- One to one relationship - comprising long term relationships and buyer-seller partnerships

- Networked - comprising strategic alliances and network organisations

Additional support for our reductionalist approach can be found in the strategy literature. Thompson et al (1991) argue that consumers fulfil their needs for goods and services by choosing between three purchasing strategies: the market place (transactional relationship), hierarchical relationships (Malone, Yates and Benjamin, 1987) or networks of consumers (Hagel and Armstrong, 1997). 
Coviello et al (2002) have a similar view of the forms of possible marketing relationships albeit they divide that which we term "relationship" into two forms of marketing: database and interaction marketing. They show that firms deploy a mixture of marketing practices that can be categorised by the form of marketing relationship by which firms engage with their consumers. Instead of investigating marketing practices like Coviello, this paper explores the Dynamic Capabilities of marketing which are developed from the extant literature on the role and function of marketing within the organisation (Appendix 1). This conceptual framework was generated from a database literature search based on combinations of the search string "the role and function of marketing". Our preliminary analysis of the literature reveals that the discussion of marketing capabilities was centred largely in this literature which has subsequently been validated by a cross disciplinary review panel consisting of senior academics from the Marketing, Strategy and Information Technology domains.

Our content analysis of the literature identifies four principal Dynamic Capabilities in marketing:

- Demand management - generating revenue for goods and services.

- Creating marketing knowledge - generating and disseminating throughout the firm - insight about consumers, markets, competitors, environmental trends, distributors, alliance partners and online communities.

- Building brands - creating and maintaining brands for products, services and the organisation. 
- Customer relationship management (CRM) - developing how the firm relates to consumers.

During the 1970s, marketing capabilities were defined in the context of facilitating transactions between firms and consumers (Kotler, 1972). The 1980s and 1990s saw the emergence of marketing as building relationships with consumers on a one-to-one basis (Pine, Peppers and Rogers, 1995) or through relationship marketing programmes (Christopher, Payne, and Ballantyne, 1991). As the internet grew in popularity, marketing scholars explored a new paradigm based upon networks of customers and their supply chains (Achrol and Kotler, 1999). This categorisation of three distinctive forms of marketing relationships resolves the apparent contradictions in the literature and is endorsed both by marketing scholars (Coviello, Brodie et al, 2002) and strategy colleagues alike (Thompson et al, 1991). Our framework, therefore, is defined by a matrix comprising these four Dynamic Capabilities set against a continuum of the three forms of marketing relationships between the firm and its customers (Figure 1): 


\begin{tabular}{|c|c|c|c|}
\hline \multicolumn{4}{|c|}{ Figure 1: A Framework of Dynamic Capabilities in Marketing } \\
\hline & $\begin{array}{l}\text { Transactional } \\
\text { relationship }\end{array}$ & $\begin{array}{l}\text { One-to-one } \\
\text { relationship }\end{array}$ & $\begin{array}{l}\text { Networked } \\
\text { relationship }\end{array}$ \\
\hline $\begin{array}{l}\text { Demand } \\
\text { management }\end{array}$ & Selling & Lifetime value & Co-creating value \\
\hline $\begin{array}{l}\text { Creating } \\
\text { marketing } \\
\text { knowledge }\end{array}$ & $\begin{array}{l}\text { Market } \\
\text { segments }\end{array}$ & $\begin{array}{l}\text { Individual } \\
\text { consumer needs } \\
\text { and purchasing } \\
\text { styles }\end{array}$ & $\begin{array}{l}\text { Key network } \\
\text { participants and } \\
\text { shapers }\end{array}$ \\
\hline Building brands & $\begin{array}{l}\text { Product and } \\
\text { service brands }\end{array}$ & Company brands & $\begin{array}{l}\text { Network } \\
\text { capabilities }\end{array}$ \\
\hline $\begin{array}{l}\text { Customer } \\
\text { relationship } \\
\text { management } \\
(\mathrm{CRM})\end{array}$ & $\begin{array}{l}\text { Contractual, } \\
\text { standardised } \\
\text { customer } \\
\text { treatment }\end{array}$ & $\begin{array}{l}\text { Differentiated, } \\
\text { customised and } \\
\text { or negotiated }\end{array}$ & $\begin{array}{l}\text { Self-managed } \\
\text { consumers } \\
\text { leveraging } \\
\text { colleagues' } \\
\text { know- how online }\end{array}$ \\
\hline
\end{tabular}

\section{Using this Framework}

\section{The Action Research Method}

As Dynamic Capabilities are highly context specific and grounded in tacit knowledge, identifying and understanding them requires enquiry from within the firm (Susman and Evered, 1978; Rouse and Daellenbach, 1999). To enable such internal deliberations, we adopted an Action Research approach (Reason and Torbert, 2001) with the managers responsible for developing CRM in the two focal firms reported here.

Action Research is a form of participatory enquiry. In this instance, the managers responsible for the successful development of CRM engage in cycles of reflection and action over a period of time using our framework (Figure 1) to generate the knowledge that they require to improve their day-to- 
day performance. These cycles of reflection and action raise managers' tacit understanding of their CRM-related routines and surface Dynamic Capabilities to the extent that they can ultimately be identified and managed. Action Research develops effective learning systems in companies (Argyris and Schön, 1978), inspires commitment to change (Clark, 1972) and can transform CRM practices (Heron and Reason, 1999). Such enquiries are led by the managers and conducted in their interests. Eden and Huxham (1996) propose certain criteria for ensuring Action Research is rigorous and contributes to scholarship. In order to contribute to scholarship, the research must have implications beyond the immediate decisions to be taken by managers in the two cases presented: in this instance, the emerging theory of Dynamic Capabilities which we contribute to developing in the context of marketing. The rigour of the research, its recoverability (Checkland and Holwell, 1998) and ability to be assessed, arises from the method and orderliness concerning the processes of collecting and reflecting upon the data generated from the two companies reported.

\section{Action Research Practices}

The companies formed cross-functional enquiry teams to assess their CRM strategies. The team leaders chaired initial meetings that established the principles of the research; that is, the authors and team members were equal co-researchers engaging in cycles of reflection and action in order to improve managers' practice as well as to create more generalised learning. The teams agreed to a series of workshops in which participating managers prepared 
formal presentations based upon workshop tools developed by the authors (Appendix 2). This preparation, combined with group discussions and agreement, promoted the cycles of learning and generated the core set of data and artefacts for analysis. The workshop tools were continually modified by the teams consistent with the democratic nature of Action Research.

Each workshop was recorded by the authors to enable preparation for future workshops, briefings and discussion. These tapes were listened to shortly after each session alongside a review of all the material generated. We followed the Argyris (1973) method of dividing a page vertically, noting the key conversation points on the left-hand side whilst on the right-hand side noting reflections during the session and reflections upon reviewing the tape. The authors also contributed expertise in workshops and to briefing material: a role that was acknowledged and appreciated by the others in the enquiry teams. In this form of Action Research, the method by which data is analysed and theory emerges is highly contextual and dependent upon the specific time and circumstances of the enquiries. The process, nonetheless, is highly replicable because it is transparent; however, other researchers following the same method with another enquiry team may not be able to replicate the results. The method produces results, in the language of Eden and Huxham, is more demonstrable than it is replicable; Checkland and Howell (1998) use the term "recoverable" to mean what Eden and Huxham call demonstrable and that permits readers of Action Research papers to assess the quality of the decisions taken and conclusions drawn. 
At the end of the research process, the authors met with team members individually and, using a semi structured questionnaire, probed to ensure that the process was democratic, the team's conclusions were accepted by the individual as valid and that the individuals were committed to the outcomes and actions agreed. Commitment to action agreed through valid information is a key test of Action Research's validity (Argyris, 1973; Clark, 1972). In total, the authors analysed over 60 hours of recorded contact time and several hundred pages of artefacts.

\section{The Action Research Process}

Figure 2 describes the process by which the two management teams used our Dynamic Capabilities framework. The framework allows each team to develop firm-specific management tools which they then use in a series of workshops over two to three months to develop a shared understanding of their current and future marketing Dynamic Capabilities in order to implement their customer strategies more effectively. A fuller explanation of these tools and how they were used is provided in Appendix 2. 
Figure 2: Using the Framework to Develop CRM Dynamic Capabilities DC

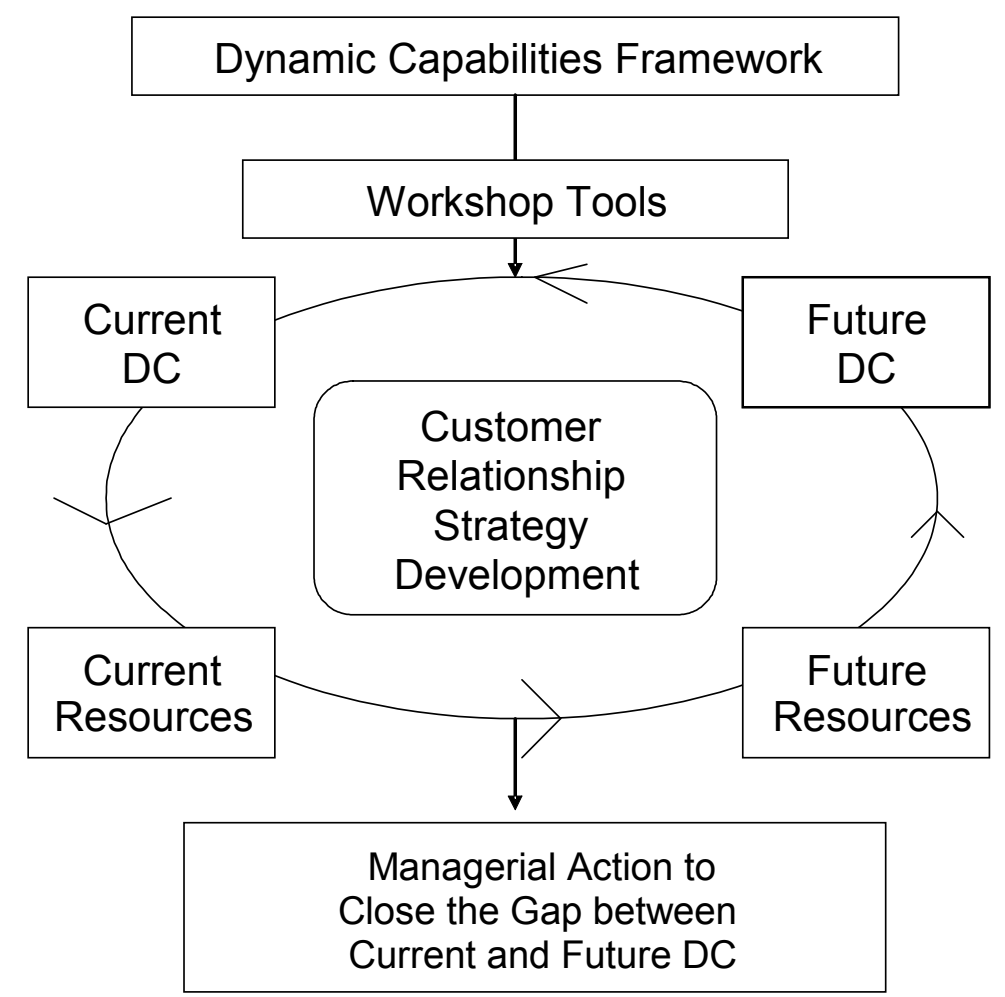

To reduce complexity and circumvent the non-linear nature of this type of research, each study is presented to the reader in short format using the following logic flow:

1. The characteristics of each focal firm from a marketing/CRM perspective

2. An overview of the Action Research process

3. The resulting actions taken by the marketing team and the rationale behind such decisions. 


\section{Findings}

This paper presents the outcomes of two such enquiries: the UK arm of a luxury car manufacturer (hereafter $\mathrm{Car}-\mathrm{Co}^{4}$ ) and a pioneer in the online betting market: hereafter Bet-Co. The selection of our enquiries follows the advice offered by Eisenhardt (1989) that studies should embrace the extremes of a phenomenon. That is, Car-Co is an established, brand-led manufacturing company whilst Bet-Co was a start up dot.com; they are at opposite ends of the spectrum with regard to CRM investment and implementation. In Action Research, there is inevitably an element of convenience sampling to ensure that it is the managers who invite the enquiry rather than the other way round.

Both companies faced market-place challenges which suggested they needed

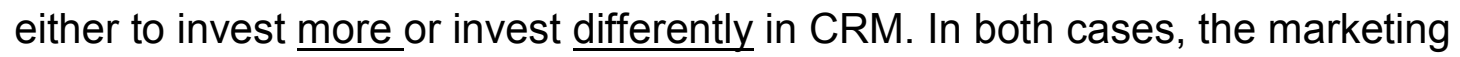
managers responsible decided first to evaluate and shape these investment decisions themselves. By agreeing to engage with us in Action Research designed to introduce a greater visibility of their respective Dynamic Capabilities supporting CRM, they are acknowledging the need to evaluate both together. In particular, both teams were looking to make explicit their assumptions about the inter-relationship between their CRM resources and related Dynamic Capabilities in order to develop marketing practices which optimised their firm's overall CRM investments. 


\section{Bet-Co}

Bet-Co was a pioneer in offering a web-based means for consumers to negotiate bets directly with other consumers. The founders expected that the social interaction it offered would create a unique community locking in consumers and their online betting friends exclusively to the Bet-Co site. The service was launched in the UK using traditional mass marketing strategies and attracted the largest number of online betters. Simultaneously, a rival entered the market with a betting exchange that aggregated and resolved bets anonymously, thus avoiding the time and complexity of having to parcel large bets for individual takers. The exchange appealed to the serious better and by the end of the launch year, the rival had $50 \%$ of the market versus BetCo's $4 \%$. In response, Bet-Co relaunched its service as a betting exchange. The marketing managers felt that they needed to offer some relationshipbased advantages to its larger competitor in order to convince large betters to use its site which was far less liquid due to the lower level of aggregate betting.

At the start of the Action Research enquiry, Bet-Co managers considered that they were retreating from relationship marketing into transactional marketing. However, through the enquiry process, they discovered that they had been effectively compensating for Bet-Co's lack of liquidity (versus its larger rival), increasing betting activity on its site whilst maintaining the necessary balance of backers and layers, winners and losers across a variety of betting interests. If, for example, a major backer of greyhounds was active, managers knew that the site would need to compensate with the activity of 20 layers because 
of the relative propensities for backing and laying amongst its greyhound betters. They had also developed a profound insight into their supply chain, knowing which of their partner web sites refer a lot of greyhound layers. Managers would increase incentives to those sites rich in greyhound-layer referrals to maintain the balance of backing and laying on the site and thus allow bets to clear. Underpinning this impressive network marketing was a profound insight into the betting preferences and behaviours of its largest betters and those betters whose standing in the community made them market-makers: people with a following who could build a market for Bet-Co quickly. Instead of Bet-Co retreating to transactional marketing, the enquiry team understood that it had moved from relationship to network marketing. Tasks undertaken as part of the enquiry confirmed that its network marketing capabilities were more advanced than its larger competitor as was its customer insight resource. It was decided that this combination of resource and Dynamic Capability was the basis of future competitiveness.

The nature of Action Research and the cycles of action and reflection meant that by the time the team decided to wind up the formal enquiry process, many of the agreed new Dynamic Capabilities had already been implemented. A new customer service programme distinguished key marketmakers from large betters and provided differentiated services to each group. A previously discontinued customer bulletin board was reinstated. Special programmes were devised for bookmakers. 
In the year that Bet-Co changed its business model from peer-to-peer betting to an exchange, and engaged in the Action Research process, its market share rose to $30 \%$.

\section{Car-Co}

Car-Co is the exclusive UK importer and distributor of Car-Co cars and is fully-owned by its worldwide holding company. Established in 1980, it has enjoyed sales growth in all but one of its nearly 30 years of trading.

The European Union (EU) had been reviewing Block Exemption, a let-out clause to the EU's free trade regime wherein car manufacturers could establish exclusive national distributors who in turn could assign exclusive sales territories to independent car dealers. It was accepted that the Block Exemption would be relaxed but no one was sure to what extent and its likely impact on automobile sales. Some worried that radical liberalisation would create more dealers, new and innovative channels to market and increased price competition, all of which would depress Car-Co's profit margins.

Against this backdrop, Car-Co's global centre was encouraging its national distributors to fund an ambitious new global CRM initiative. The UK company was already three years into its own, less ambitious, CRM programme but had not finished its implementation nor realised substantial economic benefit from it. A cross functional enquiry team led by Marketing set out to determine future CRM investment policy. 
Whilst the strength of Car-Co's global brand and its design and engineering capabilities undoubtedly drive customers to the dealerships, the enquiry revealed other Dynamic Capabilities that are also critical to its UK success: dealer and brand management. The Car-Co brand benefited from a level of consistency in positioning and advertising almost unknown in consumer marketing, evidenced by the fact that Car-Co has only had one ad agency in the UK which has engendered deep and profound understanding of the brand by a consistent cadre of managers. Car-Co also benefited from dealer relationships that were far more collaborative than is the norm in an industry characterised by acrimonious relationships between manufacturers and their dealers. The trust and commitment to common goals had kept discounting to a minimum and allowed higher residual car values, enhanced customer experience and made for more effective new car introductions.

However, managers worried that the Dynamic Capabilities that drive success today could prove less important in a radically liberalised, multi-channel environment. The dealer network, today a source of competitive advantage, was vulnerable to leaner, hungrier, CRM-savvy new channels. Allied to this concern was a realisation that the company knew very little about individual consumers because they dealt with the dealers only and not Car-Co directly. Hence managers were concerned that if the distribution environment and consumer behaviour changed radically, Car-Co could be left with a high cost dealer network and little ability to influence consumer experience and behaviour through the emerging new channels. 
During the enquiry, managers used the capability framework in a scenario planning ${ }^{5}$ context to build capabilities models and marketing approaches for varying degrees of change. Under a scenario of radical change, managers built a competency model characteristic of networked consumer relationships. They concluded that the changes in its marketing Dynamic Capabilities required to implement network marketing were contingent upon creating marketing knowledge consistent with a one-to-one consumer relationship. Without more individualised consumer understanding, it was not possible to change the remaining three Dynamic Capabilities. The firm's commitment to make these changes was not judged to be a realistic proposition without an immediate and serious threat to its business; there was too much uncertainty about any future distribution scenario to mobilise the organisation.

The managerial insights prompted a more considered approach to CRM investment. Car-Co (UK) concluded it would not be an early adaptor of the proposed corporate CRM system. Rather, it would focus its resources on finishing and leveraging its existing CRM programme and creating an owners' web site. Managers also decided to quicken the pace at which it could build consumer insight by taking the management of online consumer communication in-house and its associated analytic functions, reversing a previous decision to use third parties. In essence, Car-Co was making a "real option"6 investment (Maklan, Knox et al, 2005), a limited expenditure immediately to learn more about one-to-one marketing in order to permit it to invest in a more ambitious CRM programme in the future should changes in 
consumer behaviour and UK distribution networks warrant it. The competency framework identifies the critical Dynamic Capability in which management needed to invest immediately in order to permit that strategy to be realised.

\section{Findings about the Nature of Marketing Dynamic}

\section{Capabilities}

The authors acknowledge that findings from our two Action Research enquiries are not generalisable. Nonetheless, the role of reflective learning and the combination of inductive and deductive thinking in theory development are widely acknowledged in literature (Langley, 1999; Eden and Huxham, 1996; Eisenhardt, 1989; Argyris and Schön, 1978). Therefore, we offer the following findings as input to the process of Dynamic Capabilities theory development:

1. Dynamic Capabilities can be observed, managed and researched but the process of observation cannot easily be detached from their development. The tacit knowledge underpinning the Dynamic Capabilities supporting CRM was surfaced through cycles of reflection without compromising the firms' ability to create competitive advantage (Ambrosini and Bowman, 2001). This supports the views of those who believe that RBV research must occur within the organisation and over a series of participative interactions (Rouse and Daellenbach, 1999); detached, expert analysis is unlikely to promote the discovery process needed to observe capabilities that are grounded in tacit knowledge and organisational routines. 
2. Dynamic Capabilities develop incrementally along a continuum defined by transactional, one-to-one and network marketing relationships.

In both cases, managers moved incrementally along this marketing capabilities continuum. Bet-Co launched by recruiting many betters to a transactional relationship. Over time, it developed better insight and services for its key betters (one-to-one / relationship marketing) and based on this insight, the company was able to compensate across the site for the behaviour of key betters and leverage its market-making betters for growth (network marketing). Car-Co managers, on the other hand, experimented with network marketing in workshops but could not imagine how it would be profitable because they lacked the relationship marketing capabilities to understand fully how they would develop and profit from it. Instead, Car-Co managers plan to build consumer insight and use that as the foundation of any future relationship marketing investment. This finding suggests that investment plans based upon companies' ability to "leap-frog" from a very transactional approach to "best practice" relationship marketing (or even network marketing) is likely to fail. A company's current marketing Dynamic Capabilities limit its customer strategy options.

\section{The Dynamic Capabilities of marketing are interdependent.}

A firm cannot hope to generate demand associated with relationship marketing without having the necessary consumer insight, brand building and relationship management capabilities. Capability changes are multifaceted and do not usually occur simultaneously in a big-bang fashion. Both the firms we report on here found that their current capabilities reflect a mix of 
transaction, relationship and network marketing, although one particular kind of marketing capability was usually dominant. This finding has a direct parallel with Coviello et al (2002) who found that firms have a mixture of marketing practices across similarly defined forms of marketing.

4. The rate of capability change seems to depend on the industry context. Car-Co will develop its relationship marketing capabilities carefully over time; however, the consumer purchase cycle in that industry is approximately three years. Bet-Co evolved from transaction to relationship to network marketing in approximately one year. Its best customers used its site several times a day. This frequent contact allowed Bet-Co managers to experiment continually with different customer treatment strategies and therefore learn more quickly about its customers than Car-Co could. It is unlikely therefore that a one-size-fits-all approach to implementing CRM will prove successful; the market context creates boundary conditions for the speed of implementation. Moreover, we maintain that it would be unwise to accelerate rapidly the implementation of CRM, because capability development speed is, in part, limited by the market context.

\section{Managerial Implications}

At the beginning of this paper, the authors suggest that the level of CRM investment failure is unacceptably high and this is usually because firms invest in marketing resources without paying sufficient attention to developing 
the Dynamic Capabilities that are needed to make these investments successful. Our findings offer both hope and challenge to managers.

Dynamic Capabilities theory reassures marketing management that they can improve their CRM investments, provided they ensure that managerial practices and organisational routines evolve to support their core marketing resources. In addition, any investment in developing Dynamic Capabilities should coincide with, or even precede, investment in CRM resources. Capabilities require the active participation of managers in their development and will not develop automatically from resource investment. Makadok (2001) identifies a split amongst RBV scholars between resource pickers and resource builders; our research suggests managers must do both to be successful in CRM.

Managers directly concerned with customer management must lead the process of building Dynamic Capabilities needed to support CRM investment. The use of third parties, particularly when they wish merely to modify standardised, replicable CRM programmes, should be approached with extreme caution. The process of identifying and then developing Dynamic Capabilities requires the surfacing of tacit knowledge; by definition this is highly contextual and defies rote adoption of universal "best practice" CRM. Action Research is a legitimate means of achieving this managerial goal.

Finally, the investment case for CRM, its targets and its subsequent implementation policies, must acknowledge certain limitations upon the ability 
of managers to select any customer strategy that they chose (Mintzberg, Ahlstrand, and Lampel, 1998) and the timing of the business benefits.

Dynamic Capabilities represent a boundary condition; a company is limited by its current capabilities and the rate at which those capabilities develop is, in part, determined by the market in which the firm operates.

\section{Limitations and Further Research}

The findings of this paper are based on only two qualitative studies and are not generalisable in the same way that a positivist approach using a representative sample of companies would be. As mentioned earlier, in order to carry out Action Research effectively, both privileged access and a state of readiness among the participating management team are required if our methodology of collaborative enquiry is to provide evidence of staged progress for these managers and also to validate our results. Inevitably, this involves purposeful sampling and the limitations associated with such small sample sizes. Nonetheless, scholars have been calling for increased usage of rich-data methodologies to address the conceptual difficulties of observing Dynamic Capabilities through traditional surveys or longitudinal studies (Miller, Eisenstat and Foote, 2002) which added to our conviction that our chosen methodology was fit for purpose in this instance (Rouse and Daellenbach, 1999).

The authors identify two areas for further research. Action Research contributes to theory through cycles of action and reflection and, although it is not possible to replicate enquiries due to their context specific nature, similar 
enquiries would enhance our understanding of Dynamic Capabilities and CRM. Enquiries in industries that invest heavily in CRM systems may be particularly instructive, for instance, financial services, telephony and utilities. A second strand of research would be to work with companies in developing scale measures of Dynamic Capabilities and relate them to measures of either CRM success or business performance. Such research would allow management teams engaged in Action Research to measure their achievements and provide an incentive for enquiries to go further and deeper into Dynamic Capability development. 
Appendix One: The formative literature on Dynamic Capabilities

\begin{tabular}{|c|c|c|}
\hline Form of marketing & Author(s) & Focus of research \\
\hline \multirow{10}{*}{$\begin{array}{l}\text { Transaction } \\
\text { Marketing }\end{array}$} & Levitt $(1960 ; 1986)$ & Creating consumer demand. \\
\hline & Kotler $(1969 ; 1972)$ & Facilitating voluntary exchange. \\
\hline & Sheth (1973) & Industrial buying framework. \\
\hline & Bagozzi $(1974 ; 1975)$ & $\begin{array}{l}\text { Understanding exchange } \\
\text { process. }\end{array}$ \\
\hline & Peter, Olson (1994) & $\begin{array}{l}\text { Understanding consumer } \\
\text { behaviour. }\end{array}$ \\
\hline & Kohli, Jaworski (1990) & Market orientation. \\
\hline & Narver, Slater (1990) & Market orientation. \\
\hline & Hunt (1992) & $\begin{array}{l}\text { Marketing as understanding } \\
\text { exchange relationships. }\end{array}$ \\
\hline & $\begin{array}{l}\text { Day (1994; 1998; 1999a; } \\
\text { 1999b) }\end{array}$ & Market driven organisation. \\
\hline & $\begin{array}{l}\text { Hoffman, Novak (1996; } \\
\text { 1997; 1999; Hoffman } \\
\text { and Novak, 1997) }\end{array}$ & $\begin{array}{l}\text { Understanding consumer } \\
\text { behaviour online. }\end{array}$ \\
\hline \multirow{7}{*}{$\begin{array}{l}\text { One-to-one / } \\
\text { Relationship } \\
\text { Marketing }\end{array}$} & $\begin{array}{l}\text { Berry, Pasasuraman et } \\
\text { al }(1985 ; 1991)\end{array}$ & $\begin{array}{l}\text { Relationship marketing, quality } \\
\text { in context of service marketing. }\end{array}$ \\
\hline & $\begin{array}{l}\text { Christopher, Payne } \\
(1991 ; 1995)\end{array}$ & $\begin{array}{l}\text { Integration of marketing, } \\
\text { service and quality. }\end{array}$ \\
\hline & Craven, Piercy (1994) & $\begin{array}{l}\text { Relationship marketing } \\
\text { capabilities. }\end{array}$ \\
\hline & $\begin{array}{l}\text { (Peppers and Rogers, } \\
\text { 1994; Pine, Peppers et } \\
\text { al, 1995; Peppers and } \\
\text { Rogers, 1997) }\end{array}$ & Customer loyalty. \\
\hline & Berry (1995) & $\begin{array}{l}\text { Multiple levels of relationship } \\
\text { marketing, role of internal } \\
\text { marketing and trust. }\end{array}$ \\
\hline & Hallberg (1995) & Customer loyalty. \\
\hline & Reichheld (1996) & $\begin{array}{l}\text { Consumer, employee and } \\
\text { investor loyalty. }\end{array}$ \\
\hline \multirow{3}{*}{$\begin{array}{l}\text { Network } \\
\text { Marketing }\end{array}$} & $\begin{array}{l}\text { Gummesson (1987; } \\
1998 ; 2000)\end{array}$ & $\begin{array}{l}\text { Network/interactive model and } \\
\text { implementing relationship } \\
\text { marketing. }\end{array}$ \\
\hline & Coviello et al (2002) & $\begin{array}{l}\text { Marketing practices; comparing } \\
\text { transaction to relationship } \\
\text { mostly, some comparison to } \\
\text { network marketing. }\end{array}$ \\
\hline & Achrol, Kotler (1999) & $\begin{array}{l}\text { Identifies prototypical marketing } \\
\text { structures for network } \\
\text { marketing. }\end{array}$ \\
\hline
\end{tabular}




\section{Appendix 2: The Workshop tools}

Figure 2 describes a process of iterative workshops that build managers' appreciation for their Dynamic Capabilities. The capabilities framework and the literature (Appendix 1) that underpins it were translated into workshop tools facilitating this process, thus grounding the outcome of the enquiries in marketing theory.

There are template tools for each of the four Dynamic Capabilities in marketing which are then customised further as the managers go through the process. It is important that marketing managers adopt these tools as their own and see them as useful to improving their practice. Below is an example of the template tool for assessing CRM capabilities. It provides a score between one and three for each capability; managers generally wish to use fractions, such as 2.3 or 1.5 , to promote a sufficiently nuanced discussion of Dynamic Capabilities.

CRM Scoring Tool Used for Car-Co's Initial Evaluation of Current Capabilities

$\begin{array}{ccc}\text { Transactional } & \text { One-to-one } & \text { Networked } \\ \text { relationship } & \text { relationship } & \text { relationship } \\ (\text { Score }=1) & (\text { Score }=2) & (\text { Score }=3)\end{array}$

Measures of CRM

Score

Customer

-Product/Product group

-Profit centres with product

Governance

management

-Client managers or customer

- Community managers

segment

-Profit centres aligned to

-Profit centre model

customers

yet undetermined

Business

-Marketing plan focused on

- Customer development plans

-Breadth and depth of

Development

products and services community needs served

Product /Service

-Marketing translates

Development

consumer needs into

-Customers teach the firm,

-The firm makes its

client managers lead response,

resources available to

capture learning and

communities that drive

disseminate

innovation 
The assessment tool is calibrated for each of the four marketing Dynamic Capabilities to provide managers with an assessment of their current situation. The tools are calibrated over a number of workshops, interspersed with individual action-and-learning about relevant subjects, such as new customer service models, competitors, customer behaviour, marketing capabilities and resources. Managers prepare the results of their investigations for subsequent workshops where ideas are challenged vigorously and developed collaboratively.

Initially, the tools are used to identify current Dynamic Capabilities. Managers position each component of their marketing capabilities against the profile of their current marketing strategy: transaction, one-to-one relationship and network marketing. Managers then identify the key marketing resources associated with these Dynamic Capabilities; as resources and capabilities are highly interdependent, the identification of resources flows easily from the workshops. Then, they consider the CRM strategies that they wish to implement and determine the future resources required, paying particular attention to their most important current resources. This establishes a gap between current and future resources which can be closed by the development of future Dynamic Capabilities. Using the marketing capabilities framework, future capabilities are identified and agreement reached as to how they would be built. 


\section{Bibliography}

1. Achrol, R. and Kotler, P. (1999), 'Marketing in the Network Economy', Journal of Marketing, Vol. 63, No. Special Issue, pp. 146-163.

2. Ambrosini, V. and Bowman, C. (2001), 'Tacit Knowledge: Some Suggestions for Operationalization', Journal of Management Studies, Vol. 38, No. 6, pp. 811-829.

3. Argyris, C. (1973), Intervention Theory and Method: a Behavioural Science View, Addison-Wesley, Reading, Mass.

4. Argyris, C. and Schön, D. (1978), Organizational Learning: A Theory of Action Perspective, Addison-Wesley, Reading, Mass.

5. Bagozzi, R. (1974), 'Marketing As an Organized Behavioral System of Exchange', Journal of Marketing, Vol. 38, No. 4, pp. 77-81.

6. Bagozzi, R. (1975), 'Marketing As Exchange', Journal of Marketing, Vol. 39, No. 4, pp. 32-39.

7. Barney, J. (1991), 'Firm Resources and Sustained Competitive Advantage', Journal of Management, Vol. 17, No. 1, pp. 99-120.

8. Berry, L. (1995), 'Relationship Marketing of Services', Journal of the Academy of Marketing Science, Vol. 23, No. 4, pp. 236-245.

9. Berry, L. and Parasuraman, A. (1991), Marketing Services: Competing Through Quality, Free Press, New York.

10. Black, J. and Boal, K. (1994), 'Strategic Resources: Traits, Configurations, and Paths to Sustainable Competitive Advantage', Strategic Management Journal, Vol. 15, No. Special Issue (Summer), pp. 131-148.

11. Bohling, T., Bowman, D., LaValle, S., Mittal, V., Narayanda, D., Ramani, G. and Varadarajan, R. (2006), 'CRM Implementation: Effectiveness Issues and Insights', Journal of Service Research, Vol. 9, pp. 184-194.

12. Boulding, W., Staelin, R., Ehret, M. and Johnston, W. (2005), 'A Customer Relationship Management Roadmap: What Is Known, Potential Pitfalls, and Where to Go', Journal of Marketing, Vol. 69, No. 4, pp. 155-166.

13. Checkland, P. and Holwell, S. (1998), 'Action Research: Its Nature and Validity', Systematic Practice and Action Research, Vol. 11, No. 1, pp. 9-21.

14. Christopher, M., Payne, A. and Ballantyne, D. (1991), Relationship Marketing, Butterworth-Heinemann, Oxford. 
15. Clark, P. (1972), Action Research and Organizational Change, Harper \& Row, London.

16. Coviello, N., Brodie, R., Danaher, P. and Johnston, W. (2002), 'How Firms Relate to Their Markets: An Empirical Examination of Contemporary Marketing Practices', Journal of Marketing, Vol. 66, No. 3, pp. 33-46.

17. Cravens, D. and Piercy, N. (1994), 'Relationship Marketing and Collaborative Networks in Service Organizations', International Journal of Service Industry Management, Vol. 5, No. 5, pp. 39-53.

18. CSC Index (1994), 'CSC Index State of Reengineering Report', CSC Research Services, Vol. Special Report,

19. Day, G and Van den Bulte (2002). 'Superiority in Customer Relationship Management: Consequences for Competitive Advantage and Performance', Manuscript submitted to the Journal of Marketing.

20. Day, G. (1994), 'The Capabilities of Market-Driven Organizations', Journal of Marketing, Vol. 58, No. 4, pp. 37-52.

21. Day, G. (1998), 'What Does It Mean to Be Market-Driven?', Business Strategy Review, Vol. 9, No. 1, pp. 1-14.

22. Day, G. (1999a), The Market Driven Organisation, Free Press, New York.

23. Day, G. (1999b), 'Creating a Market-Driven Organisation', Sloan Management Review, Vol. 41, No. 1, pp. 11-22.

24. Eden, C. and Huxham, C. (1996), 'Action Research for Management Research', British Journal of Management, Vol. 7, No. 1, pp. 75-86.

25. Eisenhardt, K. (1989), 'Building Theories From Case Study From Research', Academy of Management Review, Vol. 14, No. 4, pp. 53255.

26. Eisenhardt, K. and Martin, J. (2000), 'Dynamic Capabilities: What Are They?', Strategic Management Journal , Vol. 21, No. 10-11, pp. 11051121.

27. Godfrey, P. and Hill, C. (1995), 'The Problem of Unobservables in Strategic Management Research', Strategic Management Journal, Vol. 16, No. 7 , pp. 519-533.

28. Gummesson, E. (1987), 'The New Marketing - Developing Long-Term Interactive Relationships', Long Range Planning, Vol. 20, No. 4, pp. 1020. 
29. Gummesson, E. (1998), 'Implementation Requires a Relationship Marketing Paradigm', Journal of the Academy of Marketing Science, Vol. 26, No. 3, pp. 242-249.

30. Gummesson, E. (2000), Total Relationship Marketing, ButterworthHeinemann, Oxford.

31. Hagel, J. and Armstrong, A. (1997), Net Gain, Harvard Business School Press, Boston, Mass.

32. Hagel, J. and Singer Marc (2000), 'Unbundling the Corporation', The McKinsey Quarterly, No. 3, pp. 148-161.

33. Hallberg, G. (1995), All Consumers Are Not Created Equal, Wiley, New York.

34. Heron, J. and Reason, P. (1999), 'The Practice of Co-Operative Inquiry: Research "With" People Rather Than "On" People', in Bradbury, H. and Reason, P. Handbook of Action Research, Sage, London, pp. 179-188.

35. Hoffman, D. and Novak, T. (1996), 'Marketing in Hypermedia Computer-Mediated Environments: Conceptual Foundations', Journal of Marketing, Vol. 60, No. 3, pp. 50-68.

36. Hoffman, D. and Novak, T. (1997), 'A New Marketing Paradigm for Electronic Commerce', The Information Society, Vol. 13, No. 1, pp. 4354.

37. Hoffman, D., Novak, T. and Peralta, M. (1999), 'Building Consumer Trust Online', Communications of the ACM, Vol. 42, No. 4, pp. 80-85.

38. Hunt, S. (2000), General Theory of Competition: Resources, Competencies, Productivity and Economic Growth, Sage, Beverly Hills.

39. Hunt, S. (1992), 'Marketing Is...', Journal of the Academy of Marketing Science, Vol. 20, No. 4, pp. 301-311.

40. Kale, S. (2004), 'CRM Failure and the Seven Deadly Sins', Marketing Management, Vol. 13, No. 5, pp.42-47.

41. Kohli, A. and Jaworski, B. (1990), 'Market Orientation: The Construct, Research Propositions and Managerial Implications', Journal of Marketing, Vol. 54, No. 2, pp. 1-18.

42. Kotler, P. (1972), 'A Generic Concept of Marketing', Journal of Marketing, Vol. 36, No. 2, pp. 46-54.

43. Kotler, P. and Levy, S. (1969), 'Broadening the Concept of Marketing', Journal of Marketing, Vol. 33, No. 1, pp. 10-15. 
44. Langley, A. (1999), 'Strategies for Theorizing From Process Data', Academy of Management Review, Vol. 24, No. 4, pp. 691-710.

45. Levitt, T. (1960), 'Marketing Myopia', Harvard Business Review, Vol. 38, No. 4, July-Aug, pp. 45-56.

46. Levitt, T. (1986), The Marketing Imagination, Free Press, New York.

47. Makadok, R. (2001), 'Toward a Synthesis of the Resource-Based and Dynamic-Capability Views of Rent Creation', Strategic Management Journal, Vol. 22, No. 5, pp. 387-401.

48. Maklan, S. (2004), How Should Firms Develop and or Change Their Marketing Competencies' When Developing Relationships With Consumers Online? (PhD thesis), Cranfield School of Management, Cranfield.

49. Maklan, S., Knox, S. and Ryals, L. (2005), 'Building the Business Case for CRM Investments', Long-Range Planning, Vol. 38, No. 4, pp. 3893410.

50. Malone, T., Yates, J. and Benjamin, R. (1987), 'Electronic Markets and Electronic Hierarchies', Communications of the ACM, Vol. 30, No. 6, pp. 484-497.

51. Miller, D., Eisenstat, R. and Foote, N. (2002), 'Strategy From the Inside Out: Building Capability-Creating Organizations', California Management Review, Vol. 44, No. 3, pp. 37-54.

52. Mintzberg, H., Ahlstrand, B. and Lampel, J. (1998), Strategy Safari, Prentice Hall, London.

53. Narver, J. and Slater, S. (1990), 'The Effect of a Market Orientation on Business Profitability', Journal of Marketing, Vol. 54, No. 4, pp. 20-36.

54. Newbert, S. (2007), 'Empirical Research on the Resource-Based View of the Firm: An Assessment and Suggestions for Future Research', Strategic Management Journal, Vol. 28, No. 2, pp. 121-146.

55. Parasuraman, A. , Zeithaml, V. and Berry, L. (1985), 'A Conceptual Model of Service Quality and Its Implications for Future Research', Journal of Marketing, Vol. 49, No. 4, pp. 41-50.

56. Payne, A. (2006), Handbook of CRM, Butterworth-Heinemann, Oxford.

57. Payne, A., Christopher, M., Clark, M. and Peck, H. (1995), Relationship Marketing for Competitive Advantage, Butterworth-Heinemann, Oxford.

58. Peppers, D. and Rogers, M. (1994), The One-to-One Future, Piatikus, London. 
59. Peppers, D. and Rogers, M. (1997), Enterprise One-to-One, Currency Doubleday, New York.

60. Peter, P. and Olson, J. (1994), Understanding Consumer Behavior, McGraw-Hill, New York.

61. Pine, J.I., Peppers, D. and Rogers, M. (1995), 'Do You Want to Keep Your Customers Forever?', Harvard Business Review, Vol. 73, No. 2, Mar-April, pp. 103-114.

62. Polanyi, M. (1976), 'Tacit Knowing', in Marx, M. and Goodson, F. (Editors), Theories in Contemporary Psychology, Macmillan, New York,

63. PricewaterhouseCoopers Multi-Channel Value Qualification, available at: www.pwcconsulting.com/us/pwcons.nsp/viewwebpages/crmsurvey (accessed 2002).

64. Priem, R. and Butler, J. (2001), 'Is the Resource-Based "View" a Useful Perspective for Strategic Management Research?', Academy of Management Review, Vol. 26, No. 1, pp. 22-40.

65. Reason, P. and Torbert, W. (2001), 'The Action Turn', Concepts and Transformation, Vol. 6, No. 1, pp. 1-37.

66. Reichheld, F.F. (1996), The Loyalty Effect, Harvard Business School Press, Boston, Mass.

67. Reinartz, W. and Kumar, V. (2002), 'The Mismanagement of Customer Loyalty', Harvard Business Review, Vol. 80, No. 7, pp. 86-94.

68. Rigby, D., Reichheld, F. and Schefter, P. (2002), 'Avoid the Four Perils of CRM', Harvard Business Review, Vol. 80, No. 2, pp. 101-109.

69. Rindova, V. and Kotha, S. (2001), 'Continuous "Morphing": Competing Through Dynamic Capabilities, Form and Function', Academy of Management Journal, Vol. 44, No. 6, pp. 1263-1280.

70. Roberts, M., Liu, R. and Hazard, K. (2005), 'Strategy, Technology and Organisational Alignment: Key Components of CRM Success', Journal of Database Marketing \& Customer Strategy Management, Vol. 12, No. 4, pp. 315-326.

71. Rouse, M. and Daellenbach, U. (1999), 'Rethinking Research Methods for the Resource-Based Perspective: Isolating Sources of Competitive Advantage', Strategic Management Journal, Vol. 20, No. 5, pp. 487494.

72. Ryals, L. (2005), 'Making Customer Relationship Management Work: The Measurement and Profitable Management of Customer Relationships', Journal of Marketing, Vol. 69, No. 4, pp. 252-261. 
73. Shah, D., Rust, R., Parasuraman, A., Staelin, R. and Day, G. (2006), 'The Path to Customer Centricity', Journal of Service Research, Vol. 9, pp. 113-124.

74. Sheth, J. (1973), 'A Model of Industrial Buyer Behaviour', Journal of Marketing, Vol. 37, No. 4, pp. 50-56.

75. Sheth, J. and Parvatiyar, A. (1995), 'Relationship Marketing in Consumer Markets: Antecedents and Consequences', Journal of the Academy of Marketing Science, Vol. 23, No. 4, pp. 255-271.

76. Sheth, J. and Sisodia, R. (1999), 'Revisiting Marketing's Lawlike Generalizations', Journal of the Academy of Marketing Science, Vol. 27, No. 1, pp. 71-87.

77. Srivastava, R., Shervani, T. and Fahey, L. (1998), 'Market-Based Assets and Shareholder Value: A Framework for Analysis', Journal of Marketing, Vol. 62, No. 1, pp. 2-18.

78. Susman, G. and Evered, R. (1978), 'An Assessment of the Scientific Merits of Action Research', Administrative Science Quarterly, Vol. 23, No. 4, pp. 582-603.

79. Teece, D. and Pisano, G. (1994), 'The Dynamic Capabilities of Firms: an Introduction', Industrial and Corporate Change, Vol. 3, No. 3, pp. 537-556.

80. Teece, D., Pisano, G. and Shuen, A. (1997), 'Dynamic Capabilities and Strategic Management', Strategic Management Journal, Vol. 18, No. 7, pp. 509-533.

81. Thompson, G., Frances, J., Levacic, R. and Mitchell, J. (1991), Markets, Hierarchies and Networks, Sage, London.

82. Vargo, S. and Lusch, R. (2004), 'Evolving to a New Dominant Logic for Marketing', Journal of Marketing, Vol. 68, No. 1, pp. 1-17.

83. Venkatesan, R. and Kumar, V. (2004), 'A Customer Lifetime Value Framework for Customer Selection and Resource Allocation Strategy', Journal of Marketing, Vol. 68, No. 4, pp. 106-125.

84. Webster, F. (1992), 'The Changing Role of Marketing in the Corporation', Journal of Marketing, Vol. 56, No. 4, pp. 1-17.

85. Winter, S. (2003), 'Understanding Dynamic Capabilities', Strategic Management Journal, Vol. 24, No. 10, pp. 991-995.

86. Zablah, A., Bellenger, D. and Johnston, W. (2004), 'Customer Relationship Management Implementation Gaps', Journal of Personal Selling and Sales Management, Vol. 4, pp. 279-295. 
${ }^{1}$ According to the American Customer Satisfaction Index (www.theacsi.org), customer satisfaction in 1994 was just under $75 \%$. It dipped to approximately $70.5 \%$ a few years later and has slowly climbed back to where it was in 1994, before the boom in CRM investment.

${ }^{2}$ Google Scholar estimates that this article has been cited 906 times (accessed 27.10.07).

${ }^{3}$ The authors corresponded directly with Professor Webster about the consolidation of his seven stages of marketing relationships into the three we present in this paper.

${ }^{4}$ Both the auto manufacturer and the online betting company remain anonymous.

${ }^{5}$ Scenario planning is a means by which organisations plan for highly uncertain futures, where extrapolations from current trends are inadequate. Planners identify drivers of discontinuous change, in this example online distribution, and build business models for radically different futures. These sketches of alternative futures enable managers to assess the implications of key drivers for change and make contingency plans against their potential occurrence better.

${ }^{6}$ An option is the right (not the obligation) to buy or sell an underlying asset, traditionally a financial asset, at some future time. Real Options are so called because the underlying asset is real, not financial. 